Revista Latinoamericana de la Papa 21 (2): 52 - 68

ISSN: 1853-4961

http://www.papaslatinas.org/revista.html

\title{
Management of early blight (Alternaria solani Sorauer) in processing potato crops with new fungicides - phytopathological and physiological implicancies
}

\author{
A.B. Andreu ${ }^{1}$, C. de Lasa ${ }^{2}$,P.A. Suárez ${ }^{1 / *}$, D.O. Caldiz ${ }^{3}$
}

Received: $22 / 04 / 2017$

Accepted: 06/11/2017

Accessible on line: December 2017

\section{Summary}

In Argentina, 75,000 ha of potatoes are grown annually and close to $25 \%$ of this area is grown for the processing industry. Among the impact of other diseases and pests, early blight (Alternaria solani Sorauer) infections could reduce yield by up to $20 \%$. Hence, the objective of this work was to assess the impact of a new-generation of fungicides (Boscalid + Pyraclostrobin - Bellis ${ }^{\circledR}$ - BASF Argentina) on early blight management. Results showed that foliar applications of Boscalid + Pyraclostrobin, were not only effective in controlling the disease, but they also promoted a stay-green effect and a positive impact on yield and quality in the processing cultivars Daisy and Innovator. Besides, Boscalid + Pyraclostrobin treated tubers showed an increased level of phytoalexins and stress oxidative enzymes related to defense mechanisms, such as peroxidase and polyphenol oxidase. Also, an increased deposition of cell wall reinforcement components such as phenols and lignin was observed. Thus, management of these processing varieties with Boscalid + Pyraclostrobin not only contributes to protect the foliage, but also increase yield and quality and induces the development of systemic acquired resistance that improves tuber storability.

Additional key words: Alternaria solani; Boscalid + Pyraclostrobin; stay-green effect; tuber yield; systemic acquired resistance; tuber storability.

\section{Manejo del tizón temprano (Alternaria solani Sorauer) con nuevos fungicidas en cultivos destinados al procesamiento industrial - Implicancias fitopatológicas y fisiológicas}

\section{Resumen}

En Argentina se cultivan anualmente 75,000 ha de papa, de las cuales un $25 \%$ se destinan al procesamiento industrial. Entre otras enfermedades y plagas, el tizón temprano (Alternaria solani Sorauer) puede ocasionar reducciones en el rendimiento de hasta el $20 \%$. Por lo tanto, el objetivo de este trabajo fue evaluar el impacto de una nueva generación de

\footnotetext{
Corresponding author: E-mail: psuarez@conicet.gov.ar

Instituto de Investigaciones Biológicas, Universidad Nacional de Mar del Plata - CONICET. Funes 3250, 7600 Mar del Plata, Argentina.

2 Agronomy Division, McCain Argentina SA. Ruta 226 km 61 ${ }^{500}$, B7620EMA Balcarce, Argentina.

3 Global Agronomy R\&D, Corporate Agriculture, McCain Foods Limited. Colectora Panamericana 1804, B1607CAB San Isidro, Argentina.
} 
fungicidas (Boscalid + Pyraclostrobin - Bellis ${ }^{\circledR}$ - BASF Argentina) sobre el manejo del tizón temprano. Los resultados demostraron que las aplicaciones foliares de Boscalid + Pyraclostrobin no sólo fueron efectivas para controlar la enfermedad, sino que también promovieron un efecto stay-green y un impacto positivo sobre el rendimiento y la calidad en los cultivares Daisy e Innovator. Además, los tubérculos provenientes de las plantas tratadas con Boscalid + Pyraclostrobin mostraron un aumento en el nivel de fitoalexinas y de las enzimas oxidativas del estrés relacionadas con mecanismos de defensa, como la peroxidasa y la polifenol oxidasa. También se encontró una mayor acumulación de compuestos capaces de reforzar la pared celular, como fenoles y lignina. Por lo tanto, el manejo de estas variedades con Boscalid + Pyraclostrobin no solo contribuyó a proteger el follaje, sino también a aumentar el rendimiento y la calidad, e indujo el desarrollo de resistencia sistémica adquirida, lo cual mejora la almacenabilidad de los tubérculos.

Palabras clave adicionales: Alternaria solani; Boscalid + Pyraclostrobin; efecto staygreen, rendimiento, resistencia sistémica adquirida, almacenabilidad.

\section{Introduction}

In Argentina, close to 75,000 ha of potatoes are grown all year-round in different regions (Constantino 2016), and $25 \%$ of this area is grown for the processing industry (Napolitano 2012). Most of the processing crops for chips and French fries are grown in the Southeast area of the province of Buenos Aires where the main foliar diseases reducing yield are late (Phytophthora infestans (Mont.) De Bary and early blight (Alternaria solani Sorauer). Late blight is the most severe disease and under certain agro-ecological conditions caused severe yield and quality reductions in the area under study (Mantecón 2007). A. solani, first described in 1882 by Zachmann, is a pathogen present in all potato growing areas and opposite to what its name suggests, appears after crop flowering or during early crop senescence (Stevenson 1993). However, a warm and humid season contributes to an early development of the disease, causing a major impact on yield (Wale et al. 2008). In Argentina, yield losses up to $18 \%$ have been registered due to the incidence of early blight (Mantecón 2015), although in other countries, yield losses over $20 \%$ have been also evaluate assessed
(Stevenson et al. 2001).

During the last decades the same fungicides used to control late blight were also used to control early blight, for example: mancozeb, chlorothalonil and triphenyl acetate (Escande et al. 1984) The development of triazoles, such as tebuconazole, difeconazole and flutriafol, commonly used in Argentina, have also played an important role in the management of early blight, as with the appearance of strobirulins (CASAFE 2009). Bellis ${ }^{\circledR}(25.2 \%$ Boscalid $+12.8 \%$ Pyraclostrobin) is an association of an anilide (a trans-laminar systemic fungicide, with preventive and curative effects) with a strobilurin, that not only prevents early blight infections but also promotes a stay-green effect.

After harvest, potato tubers could be susceptible to rotting due to different diseases that appear during handling and storage. Then, it is possible to take advantage of the mechanism known as induced resistance (IR) to protect tubers from various diseases (Ryals et al. 1996; Soleiman et al. 2012). This has been demonstrated by the systemic fungicide Fosetyl-aluminum $\quad(80 \%$ try-O-methyl aluminum phosphate, Aliette 80 WG, 
Bayer Crop Science, Argentina) which induced disease resistance in harvested tubers and also showed an increase in level of $\beta$-1,3-glucanase protein and aspartyl protease, as well as in the content of phenols and phytoalexins (Andreu et al. 2006).

On the other hand, it could also be considered that the expression of IR has a cost, due to the allocation of plant resources to defense mechanisms rather than to growth or reproduction (Heil 2001). In this case, the activation of the disease mechanisms during IR may not necessarily be accompanied by an increase in yield or improved quality of processing potatoes. Understanding the biochemical interactions occurring between plants, pathogens and those compounds capable of developing IR could provide useful information for the optimization of disease control.

The purpose of this research was to assess the effect of a new fungicide Boscalid + Pyraclostrobin (Bellis ${ }^{\circledR}$, BASF Argentina), on crop growth, tuber yield and quality of processing potato crops as well as the contribution to the development of induced disease resistance in harvested tubers.

\section{Materials and Methods}

\section{Field experiments}

\section{Site and Varieties Used}

The work was carried out during the growing seasons 2008/09 and 2009/10. During 2008/09 field trials were carried out at the McCain Argentina SA Experimental Field (Balcarce, SL $37^{\circ}$ 49, 115 m.a.s.l.), while during 2009/10 trials were performed at $\mathrm{La}$ Alianza Farm (Loberia, SL $38^{\circ}$ 21', 48 m.a.s.1.), province of Buenos Aires, Argentina over a complex Typical Argiudols. In both seasons, trials were carried out with cultivars used for processing into French fries. In 2008/09, certified seed pieces, 50 g each, of cultivars Daisy and Innovator, while in $2009 / 10$ only cultivar Innovator was used.

\section{Experimental Design and Crop Management}

The trials were carried out in a randomized block design in plots of 12 rows (12 m long x $0.85 \mathrm{~m}$ apart) with three replicates for treatment. In both seasons crops were frequently irrigated with a sprinkler system based on Watermark soil humidity sensors. Weeds control, insect control and fertilization were conducted according to standard recommended practices for the region for each specific cultivar (Caldiz 2004, Hernández et al. 2006). In 2008/09 planting was done on 23 October 2008 with a 4-row planter at a density of 5 seed pieces per linear meter for cvs. Innovator and Daisy and $80 \%$ emergence occurred on 12 November 2008. In 2009/10, the $\mathrm{cv}$. Innovator was planted on 12 October 2009 with a 4-row planter at the same density, and $80 \%$ emergence occurred on 12 November 2009.

\section{Treatments}

Treatments for each season were the following. For 2008/09 (T1) Control, no fungicides were applied; (T2) Tebuconazole 25\%, 0.5 liter ha (Folicur® 25 EW, Bayer Crop Science, Argentina); (T3) Boscalid 25.20\% + Pyraclostrobin $12.80 \%$, 0.25 liter ha ${ }^{-1}$ (Bellis ${ }^{\circledR}$, BASF Corporation, Argentina). For 2009/10 (T1) Control, no fungicides were applied; (T2) Tebuconazole 25\%, 0.5 liter ha ${ }^{-1}$; (T3) Azoxystrobin + Difenoconazole, 0.5 liter ha ${ }^{-1}$ (Amistar Top®, Syngenta, Argentina); (T4) Boscalid $25.20 \%+$ Pyraclostrobin $12.80 \%, 0.25$ liter ha ${ }^{-1}$ starting at 60 days after planting; and (T5) Boscalid 25.20\% 
+ Pyraclostrobin $12.80 \%, 0.25$ liter ha $^{-1}$ starting at 75 days after planting.

\section{Field evaluations}

To assess early blight at field level the Horsfall and Barratt (1945) visual scale was used. During crop growth, in 20 plants per replication, the percentage ground cover (GC) according to CIP (1986) procedures was evaluated. The green index (GI) was assessed with a Minolta chlorophyll meter $\left(4^{\text {th }}\right.$ expanded leaf from the top). Ground cover duration (GCD) was calculated as the sum of all $\mathrm{GC}$ values during the season for each cvs. and treatment. In both seasons, crops were allowed to die naturally to observe differences in crop growth and early blight incidence. Harvest was carried out manually, 137 and 167 days after planting for 2008/09 and 2009/10 crops, respectively. In each case, all tubers from a 4-row section of 3 linear meters per replication (center rows) were harvested. Samples of harvested tubers were taken to the McCain Argentina Receiving Laboratory, where they were weighed and graded $(<50$ and $>50 \mathrm{~mm})$ to establish tuber size distribution. The percentage of dry matter (\% DM) of the tubers was obtained by the gravimetric method.

\section{Post-harvest tuber assessment}

After harvest, all tubers from a 2-row section of 3 linear meter per replication from the fungicide-treated and control plots were stored at $10{ }^{\circ} \mathrm{C}$ and $95 \%$ relative humidity $(\mathrm{RH})$ for three months for subsequent assays.

\section{Laboratory experiments}

Biological studies Phytophthora infestans race R2 R3 R6 R7 R9, mating type A2, was isolated and cultivated as described by Andreu et al. (2006).
The pathogenic fungus Fusarium solani $\mathrm{f}$. sp. eumartii isolate 3122 ( $F$. solani) from INTA Balcarce, Argentina, collection was used in this trial (Andreu et al. 2006).

\section{Evaluation of tuber protection}

For studies on the tuber response to late blight, 20 undamaged tubers per field replication were cut (two slices per tuber (4-6 $\mathrm{cm}$ diameter, $10 \mathrm{~mm}$ thick)) and inoculated with $50 \mu \mathrm{l}$ of the sporangial suspension of $P$. infestans $(40 \quad 000$ sporangia $\mathrm{ml}^{-1}$ ). Inoculated tuber slices were incubated in darkness at $15{ }^{\circ} \mathrm{C}$. The largest diameter of mycelium was measured on the upper surface of the slices after 7 days, when tuber slices were completely covered with mycelium.

Dry rot severity was evaluated in 10 tubers per field replication. $F$. solani disk of the fungus grown on PDA medium was introduced into the tuber cortical tissue, according to the hollow punch method (Olivieri et al. 1998). Inoculated tubers were incubated in darkness at $25{ }^{\circ} \mathrm{C}$ over 16 days. At this time, the tubers were cut longitudinally, and disease severity was evaluated using an arbitrary scale of $0=$ no symptoms, $1=<2.5 \%$ of cut area with symptoms, $2=2.5-10 \%$ cut area with symptoms, $3=>10-25 \%$ cut area with symptoms, $4=>25-50 \%$ cut area with symptoms and $5=>50 \%$ cut area with symptoms of susceptibility.

\section{Determination of phytoalexins, phenols} and lignin compounds

Seven days after the infection with $P$. infestans, phytoalexins and phenols were extracted according to Andreu et al. (2006). Phytoalexins were quantified according to the method described by Shih and Kuc (1973) and phenols quantification by Bray and Thorpe (1954). 
At the same time, lignin was extracted according to the method described by Bruce and West (1982).

Peroxidase and polyphenol oxidase activities

\section{Data analysis}

Field results were analyzed statistically using ANOVA (Zar 1999) with the SigmaStat ${ }^{\circledR}$ program (SYSTAT version 10.2 ) at a confidence level $\mathrm{P}<0.05$. In the postharvest tubers, area showing late blight, dry rot lesion symptoms, phytoalexins, phenols and lignin content were analyzed by the $t$-test. Enzyme content and activity data were analyzed by one-way ANOVA and a posteriori multiple comparison Tukey test were performed when significant differences ( $\mathrm{P}$ $<0.05)$ between means were detected.

\section{Results}

\section{Early blight severity}

During the season 2008/09 no incidence of $A$. solani was observed, because the environmental conditions did not favor disease development. During the 2009/10 season, environmental conditions favored the appearance of early blight, at 105 days after planting (DAP). The incidence of the disease was different between
Peroxidase (POX) and polyphenol oxidase (PPO) activities were determined in the crude extracts according to the procedure described by Chen et al. (2000), with some modifications.

treatments. The presence of the disease had a greater incidence in the control treatments, Tebuconazol and Azoxystrobin + Difenoconazole with respect to the treatment with Boscalid + Pyraclostrobin.

Crop variables, tuber yield and tuber quality

During 2008/09 although no significant differences in GC were observed (Figure 1), significant differences in the GI for both varieties after 80 DAP were achieved (Figure 2). For the trial carried out during the 2009/10 in Innovator, significant differences were observed in GC, at 110 DAP (Figure 1) and in the GI at 85 DAP (Figure 2). Probably the dry and windy season (2008/09) enhances crop senescence and limited the greening effect attributed to Boscalid + Pyraclostrobin. However, during 2009/10 an positive effect was observed on the GI (Figure 2), and for both seasons a positive relationship was found between GCD and tuber yield (Figure 3). 

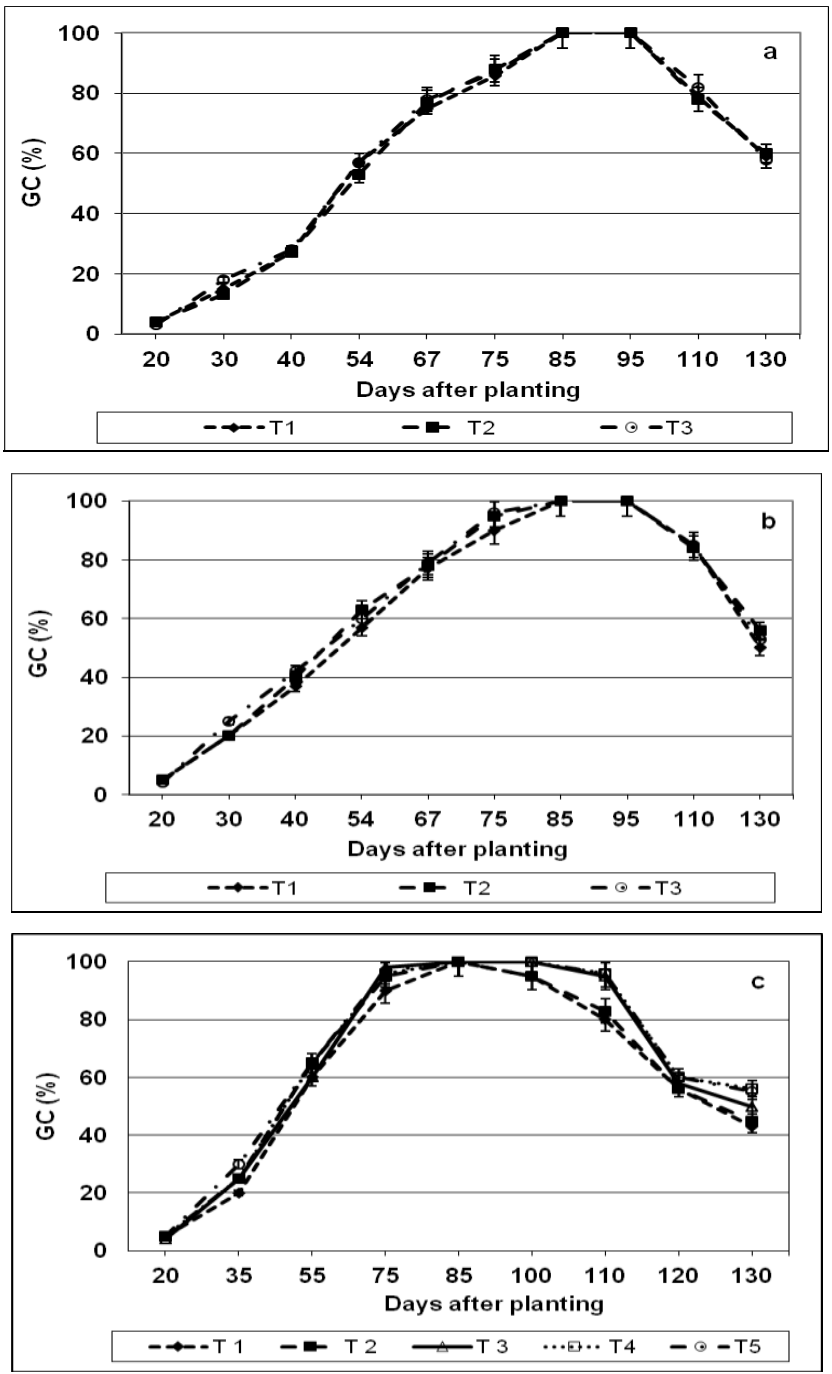

Figure 1. Ground cover (GC)

(a) Daisy and (b) Innovator Balcarce 2008/09: T1 (•): Control; T2 (•): Tebuconazole; T3 (॰): Boscalid + Pyraclostrobin; and (c) Innovator, Loberia 2009/10: T1 (•): Control; T2 (•), Tebuconazole; T3 $(\Delta)$ : Azoxystrobin + Difenoconazole; T4 ( $\square)$ : Boscalid + Pyraclostrobin starting at 60 DAP; T5 (०): Boscalid + Pyraclostrobin - starting at 75 DAP. 

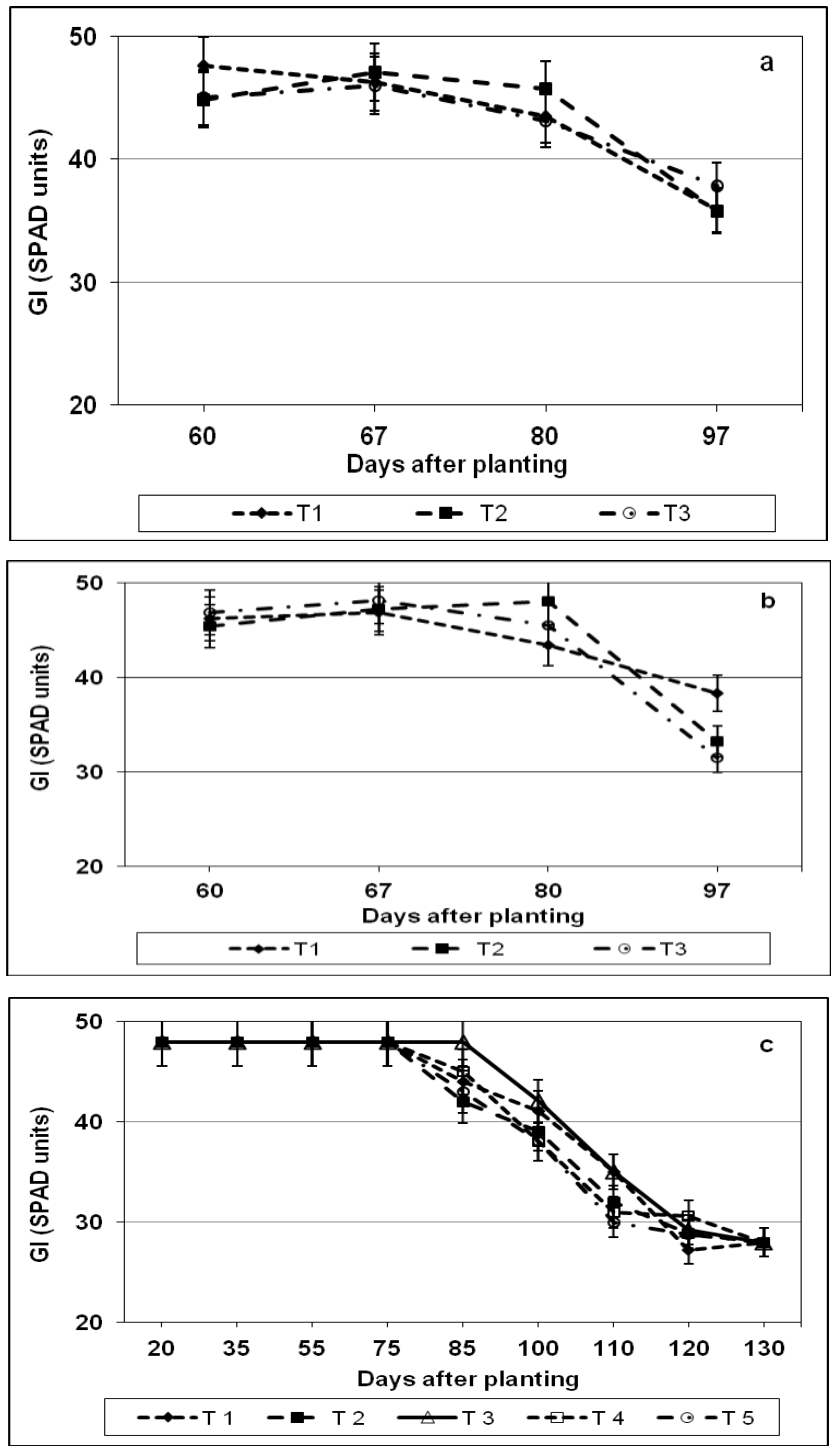

Figure 2. Green index (GI)

(a) Daisy and (b) Innovator, Balcarce 2008/09: T1 (•): Control; T2 (•): Tebuconazole; T3 (॰): Boscalid + Pyraclostrobin; and (c) Innovator, Lobería 2009/10: T1 (•): Control; T2 (•): Tebuconazole; T3 $(\Delta)$ : Azoxystrobin + Difenoconazole; T4 (ם): Boscalid + Pyraclostrobin starting at 60 DAP; T5 $\left({ }^{\circ}\right)$ : Boscalid + Pyraclostrobin - starting at 75 DAP. 
a

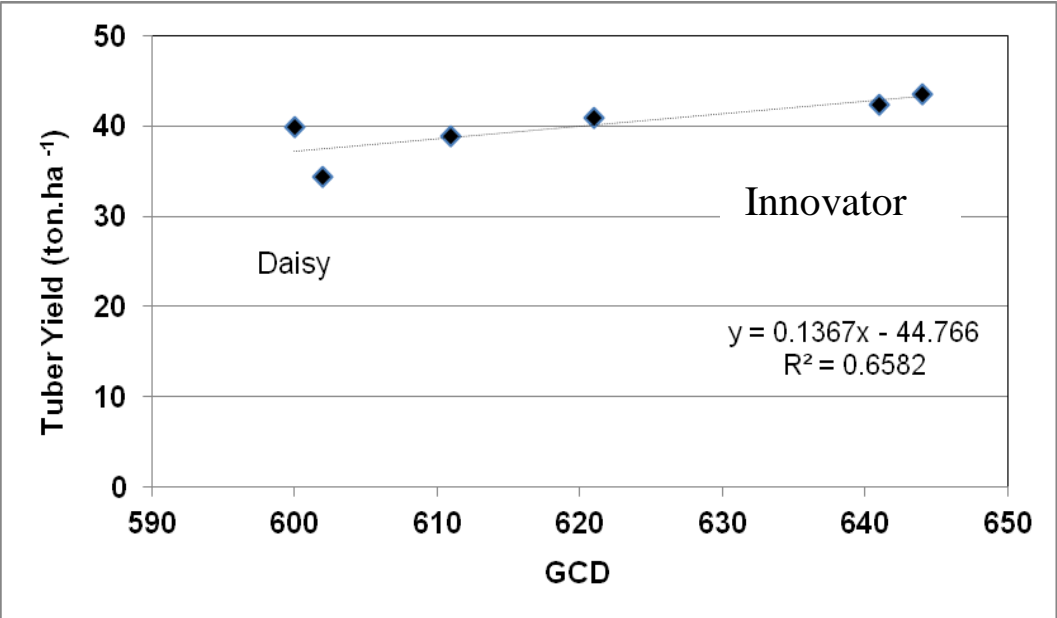

b

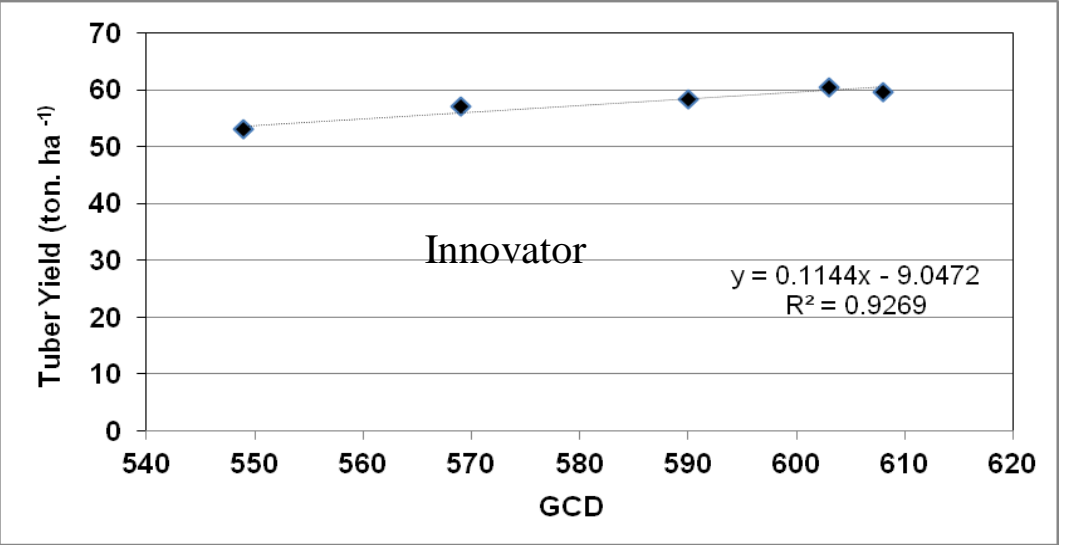

Figure 3. Relationship between GCD and Yield

(a) Daisy and Innovator, Balcarce 2008/09. (b) Innovator, Loberia 2009/10. 
Table 1. Tuber yield and tuber quality, Balcarce 2008/09.

\begin{tabular}{|c|c|c|c|}
\hline Treatment & $\begin{array}{c}\text { Yield } \\
\left(\mathrm{t} \mathrm{ha}^{-1}\right)\end{array}$ & $\mathrm{DM}(\%)$ & $\begin{array}{l}\text { DM Yield } \\
\left(\mathrm{t} \mathrm{ha}^{-1}\right)^{1}\end{array}$ \\
\hline \multicolumn{4}{|l|}{ Daisy } \\
\hline $\mathrm{T} 1$ & $34,36 \mathrm{~b}$ & $17,75 b$ & $6,10 b$ \\
\hline $\mathrm{T} 2$ & $39,86 \mathrm{a}$ & $18,65 \mathrm{a}$ & $7,43 \mathrm{a}$ \\
\hline $\mathrm{T} 3$ & $38,93 \mathrm{a}$ & $18,73 \mathrm{a}$ & 7,29 a \\
\hline \multicolumn{4}{|l|}{ Innovator } \\
\hline $\mathrm{T} 1$ & $40,88 \mathrm{a}$ & $17,86 b$ & $7,30 \mathrm{c}$ \\
\hline $\mathrm{T} 2$ & $42,39 a$ & $17,83 \mathrm{~b}$ & $7,56 \mathrm{~b}$ \\
\hline $\mathrm{T} 3$ & $43,51 \mathrm{a}$ & $18,29 \mathrm{a}$ & 7,96 ab \\
\hline
\end{tabular}

T1: Control; T2: Tebuconazole; T3: Boscalid + Pyraclostrobin. ${ }^{1}$ Calculated as: [Tuber yield * DM\%] / 100. Figures within the same column and the variable followed by the same letter do not differ between them at a $P$ value of 0.05 .

Table 2. Tuber yield and tuber quality, Lobería 2009/10

\begin{tabular}{lccc}
\hline Treatment & $\begin{array}{c}\text { Yield } \\
\left(\mathrm{t} \mathrm{ha}^{-1}\right)\end{array}$ & DM (\%) & $\begin{array}{r}\text { DM Yield } \\
\left(\mathrm{t} \mathrm{ha}^{-1}\right)^{1}\end{array}$ \\
\hline Innovator & & & \\
T1 & $53,03 \mathrm{~b}$ & $18,14 \mathrm{a}$ & $9,62 \mathrm{~b}$ \\
T2 & $57,04 \mathrm{ab}$ & $17,27 \mathrm{~b}$ & $9,85 \mathrm{~b}$ \\
T3 & $58,44 \mathrm{ab}$ & $17,35 \mathrm{~b}$ & $10,14 \mathrm{ab}$ \\
T4 & $60,45 \mathrm{a}$ & $17,65 \mathrm{a}$ & $10,67 \mathrm{a}$ \\
T5 & $59,66 \mathrm{a}$ & $17,06 \mathrm{~b}$ & $10,18 \mathrm{a}$ \\
\hline
\end{tabular}

T1: Control; T2: Tebuconazole; T3: Azoxystrobin + Difenoconazole; T4: Boscalid + Pyraclostrobin - starting at 60 DAP; T5: Boscalid + Pyraclostrobin - starting at 75 DAP. ${ }^{1}$ Calculated as: [Tuber yield *DM\%] / 100.

Figures within the same column followed by the same letter do not differ between them in $a$ $P$ value of 0.05 . 
a Phytophthora infestans
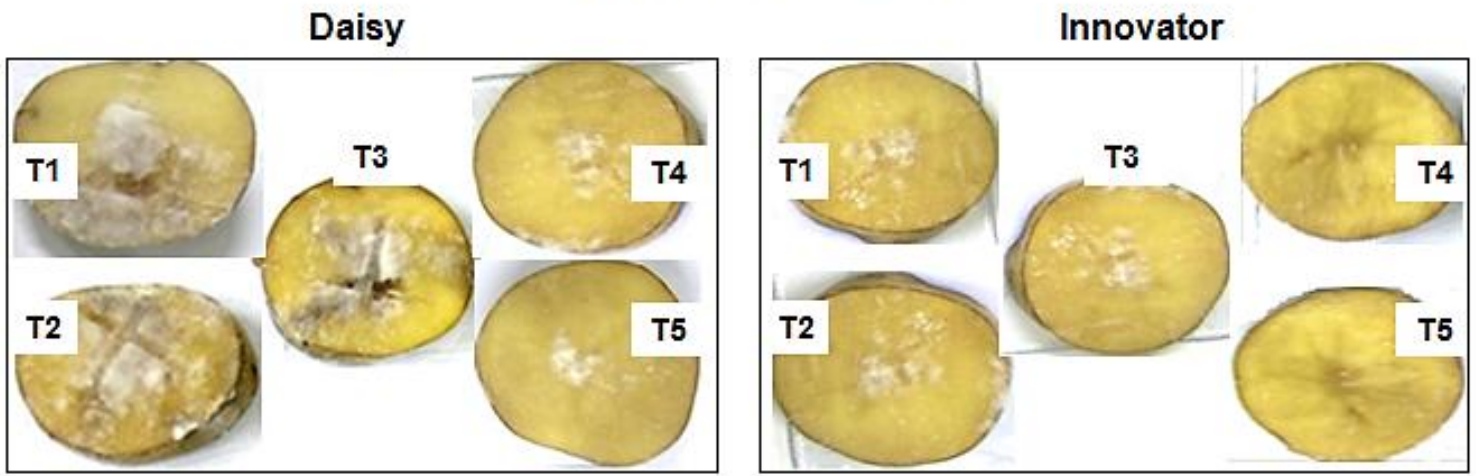

b

Fusarium solani
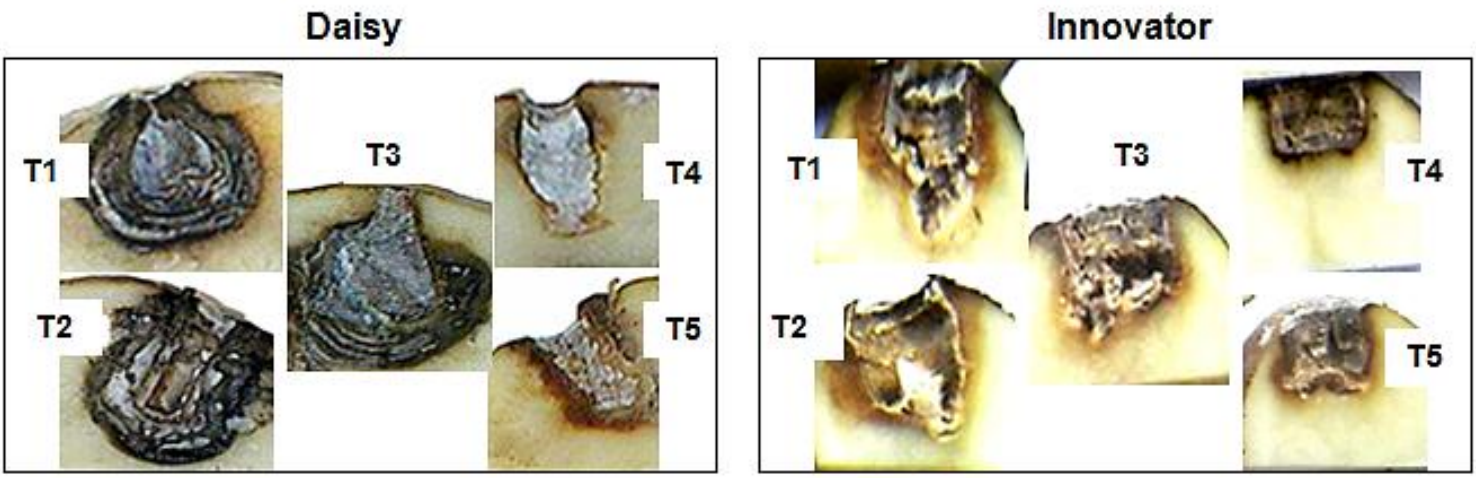

Lesion area $\left(\mathrm{cm}^{2}\right) *$

c

\begin{tabular}{ccccc} 
& \multicolumn{2}{c}{ P. infestans } & \multicolumn{2}{c}{$F$ solani } \\
\cline { 2 - 5 } Treatment & Daisy & Innovator & Daisy & Innovator \\
\hline T1 & $10.40 \pm 0.40 \mathrm{a}$ & $3.50 \pm 0.30 \mathrm{a}$ & $3.75 \pm 0.89 \mathrm{a}$ & $3.20 \pm 0.50 \mathrm{a}$ \\
T2 & $9.80 \pm 1.50 \mathrm{a}$ & $3.40 \pm 0.30 \mathrm{a}$ & $4.20 \pm 0.30 \mathrm{a}$ & $3.30 \pm 0.40 \mathrm{a}$ \\
T3 & $9.90 \pm 1.20 \mathrm{a}$ & $3.45 \pm 0.20 \mathrm{a}$ & $4.80 \pm 0.75 \mathrm{a}$ & $3.50 \pm 0.35 \mathrm{a}$ \\
T4 & $1.65 \pm 0.30 \mathrm{~b}$ & $0.20 \pm 0.02 \mathrm{~b}$ & $1.20 \pm 0.30 \mathrm{~b}$ & $0.90 \pm 0.20 \mathrm{~b}$ \\
T5 & $1.30 \pm 0.20 \mathrm{~b}$ & $0.10 \pm 0.05 \mathrm{~b}$ & $1.15 \pm 0.22 \mathrm{~b}$ & $1.00 \pm 0.10 \mathrm{~b}$ \\
\hline
\end{tabular}

*For each fungus and cultivar, values followed by same letter are not significantly different according to the $t$-test, at a $P$ value of 0.05 .

Figure 4. Post-harvest tuber assessment against Phytophthora infestans and Fusarium solani.

(a) Symptoms caused by P. infestans for each treatment; (b) Symptoms caused by $F$. solani f. sp. eumartii for each treatment; and (c) Lesion area for each disease $\left(\mathrm{cm}^{2}\right)$. Treatments: T1: Control; T2: Tebuconazole; T3: Azoxystrobin + Difenoconazole; T4 and T5: Boscalid + Pyraclostrobin - starting at 60 and 75 DAP respectively. 
During the season 2008/09 in cv. Daisy, both fungicide treated plots (Tebuconazole, and Boscalid + Pyraclostrobin) showed a higher yield, than the control. Dry matter percentages also showed a similar trend; they were higher in the fungicide treated plots than in the control plots. Consequently, total dry matter produced was significantly higher in the treatments than in the control (Table 1). In Innovator, there were no significant differences in yield, but there was a clear trend to achieve a higher yield when Boscalid + Pyraclostrobin was applied, but in this case, there was not an effect on the dry matter percentage, although the total dry matter produced was higher in the fungicide treated plots (Table 1). During the 2009/10 season, Boscalid + Pyraclostrobin - treated plots showed a yield increase, at 60 and 75 DAP 8 and $9 \%$, respectively (Table 2 ). Dry matter percentages did not show a clear trend; however, due to higher yields achieved in the Boscalid + Pyraclostrobin treated plots at 60 and $75 \mathrm{DAP}$, total dry matter production was much higher in these treatments compared with the control and Tebuconazole, but without differences with the Azoxystrobin + Difenoconazole treatment (Table 2).
Effect on late blight and dry rot protection in post-harvest tuber

Treatment with Boscalid + Pyraclostrobin during crop growth led to a significant increase in tuber resistance to late blight and dry rot after harvest. In both cultivars, Daisy and Innovator, a reduction in the lesion size produced by $P$. infestans and $F$. solani was observed. For these two pathogens the lesion area in tubers coming from Boscalid + Pyraclostrobin treated plants was reduced by approximately $70 \%$ with respect to the lesion size produced in tubers without fungicide or other with fungicide treatments (Figure 4).

Phytoalexins, phenols and lignin accumulation in post-harvested tubers

Tuber slices infected with P. infestans from plants treated with Boscalid + Pyraclostrobin showed high levels of phytoalexins and phenols in both seasons and cultivars (five-fold and two-fold, respectively), when compared with nontreated plants and with Tebuconazole or Azoxystrobin + Difenoconazole treated plots (Figure 5a and 5b). The content of lignin was also significantly higher in tubers coming from the Boscalid + Pyraclostrobin treated plots than in those from the control or other fungicides treated plots (Figure 6). 
$\mathbf{a}$

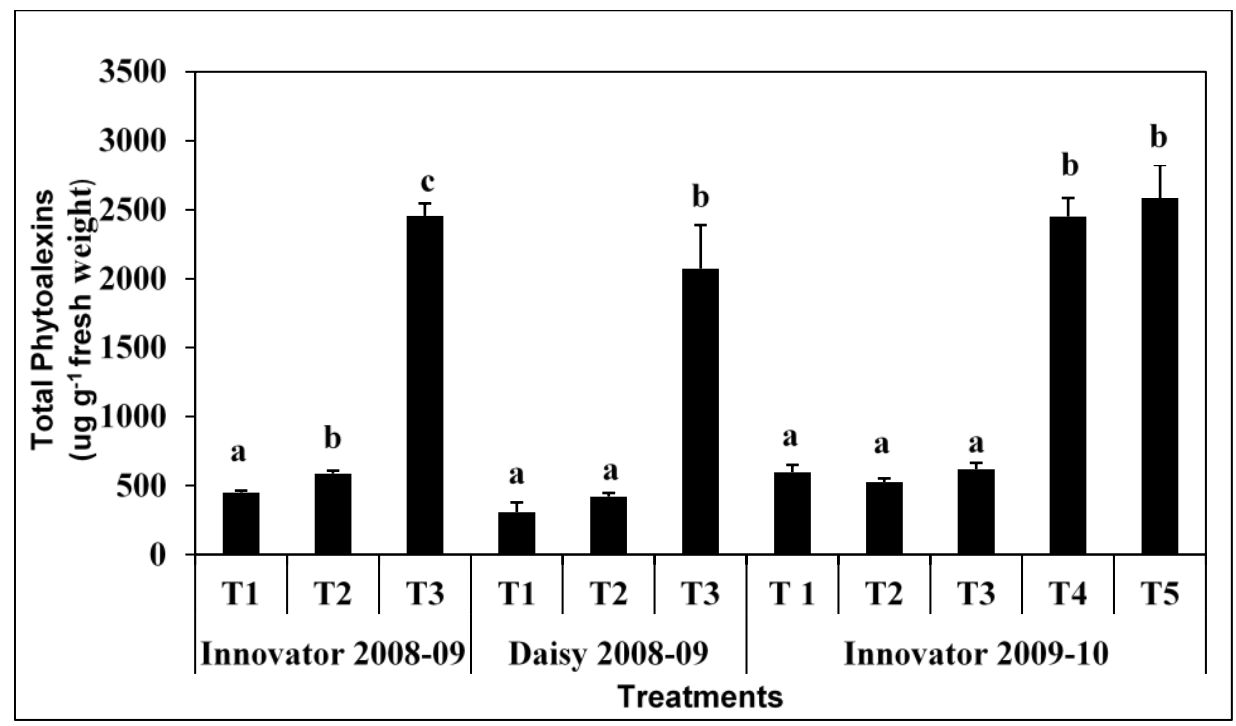

b

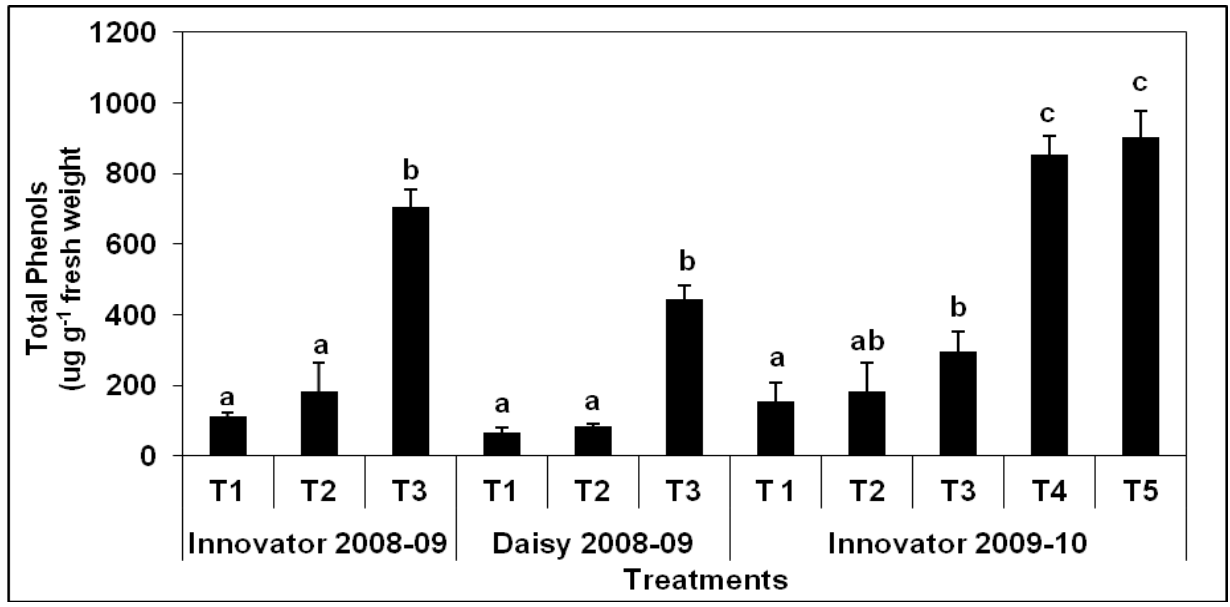

Figure 5. Phytoalexins (a) and soluble phenols (b) accumulation in post-harvest tubers.

Level of phytoalexins in Daisy and Innovator, Balcarce 2008/09, and soluble phenols in Innovator, Loberia 2009/10, were quantified in tuber slices of tuber from control and treated plants after Phytophthora infestans inoculated. Treatments: 2008/09: T1: Control; T2:
Tebuconazole and T3: Boscalid + Pyraclostrobin; and 2009/10; where T1: Control, T2: Tebuconazole; T3: Azoxystrobin + Difenoconazole; T4 and T5: Boscalid + Pyraclostrobin application at 60 and 75 DAP respectively. 


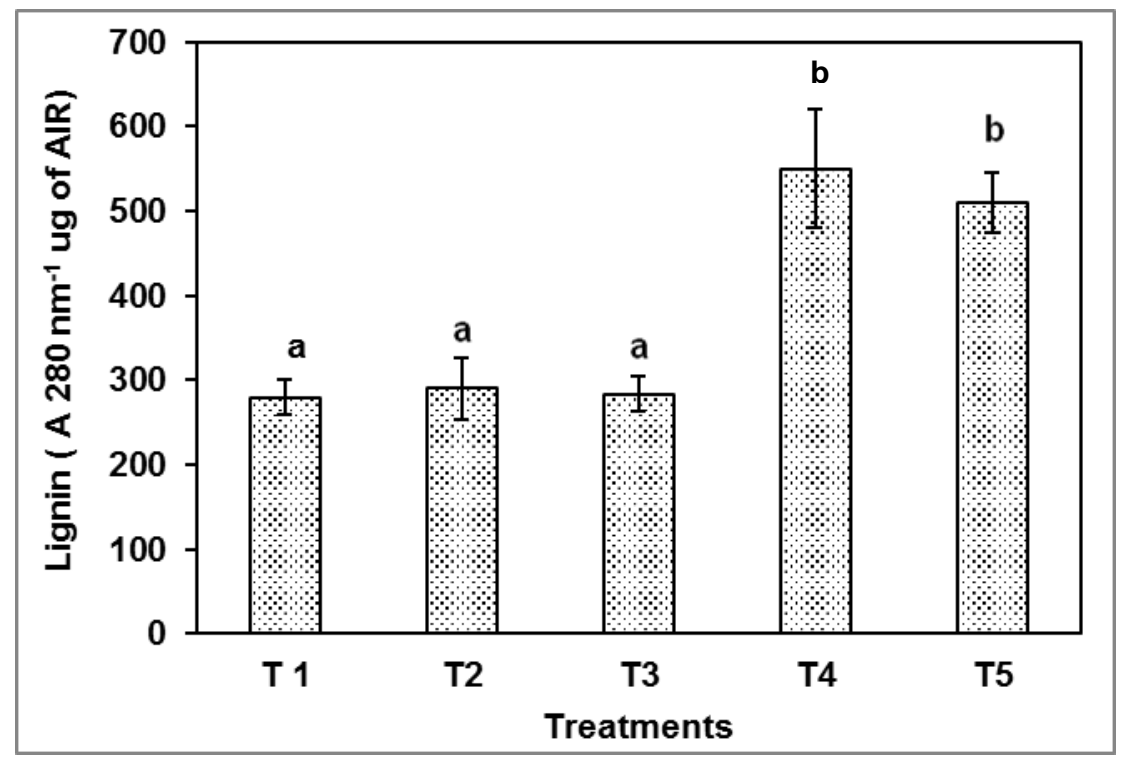

Figure 6. Lignin content in post-harvest tubers.

Content of lignin in Innovator, Loberia 2009/10, were quantified in tuber slices of tuber from control and treated plants after $P$. infestans inoculated. Treatments: T1: Control; T2: Tebuconazole; T3: Azoxystrobin + Difenoconazole; T4 and T5: Boscalid + Pyraclostrobin application at 60 and 75 DAP respectively.

\section{Peroxidase and polyphenol oxidase activities in harvested tubers}

In order to know if stress oxidative enzymes could participate in the defense mechanism induced by Boscalid + Pyraclostrobin, peroxidase (POD) and polyphenol oxidase (PPO) activities were assessed in post-harvest tubers. POD and PPO activities were quantified at different times after $P$. infestans inoculation in tuber slices or wounding (non-infected tuber slices). For POD activity, major values were obtained $72 \mathrm{~h}$ after inoculation. At this time, the activity increased up to $50 \%$ in infected tubers obtained from Boscalid + Pyraclostrobin treated plants than in those tubers from Tebuconazole or Azoxystrobin + Difenoconazole treated plots (Figure 7a). Results of PPO activity show a similar behavior, but the activity peak was detected earlier, $12 \mathrm{~h}$ after inoculation or wounding. At these times, tubers obtained from Boscalid + Pyraclostrobin - treated plants showed an increase in PPO activity of approximately six - fold with respect to infected tubers obtained from Tebuconazole or Azoxystrobin + Difenoconazole treated or non-treated (Figure 7b). 
$\mathbf{a}$

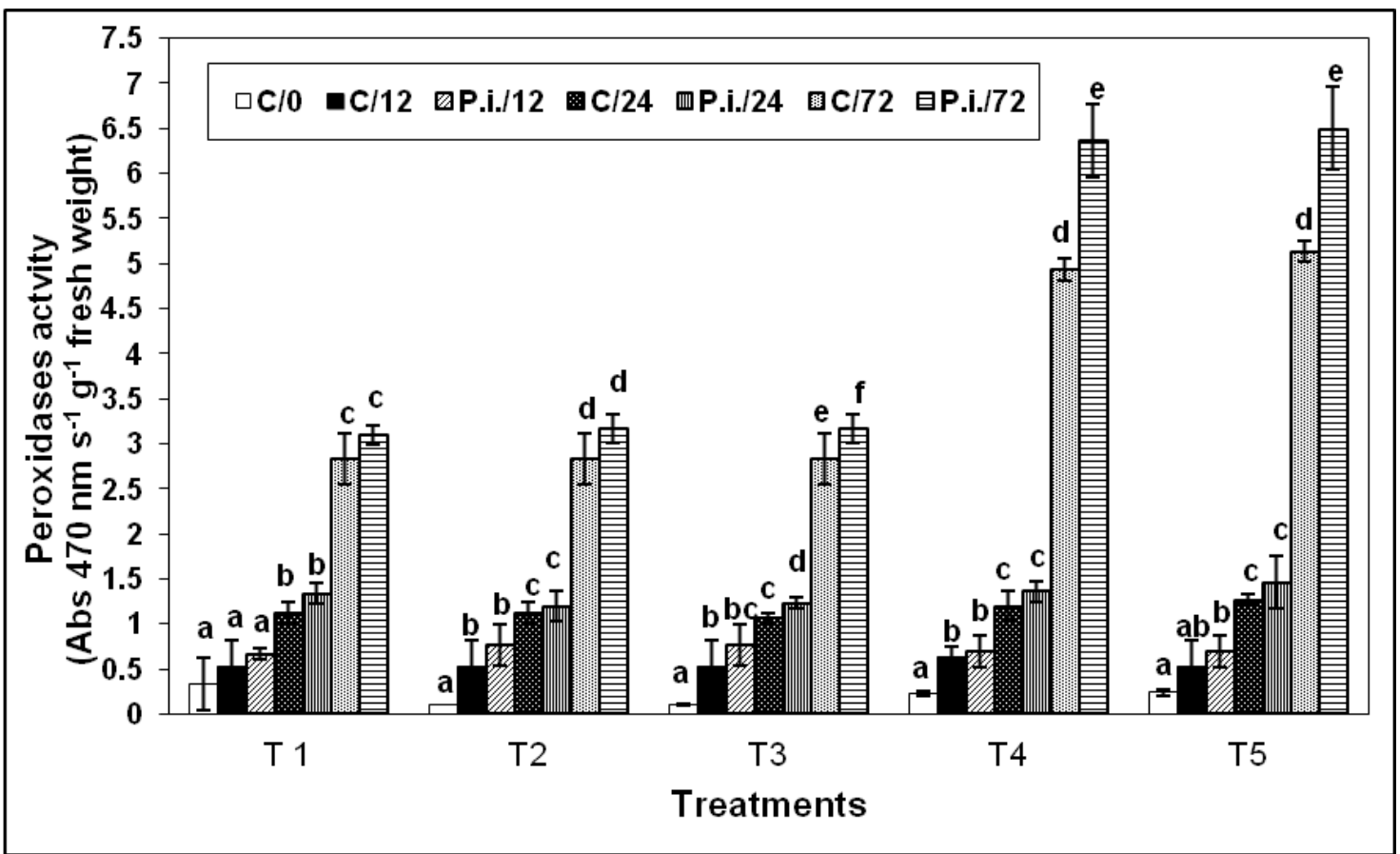

b

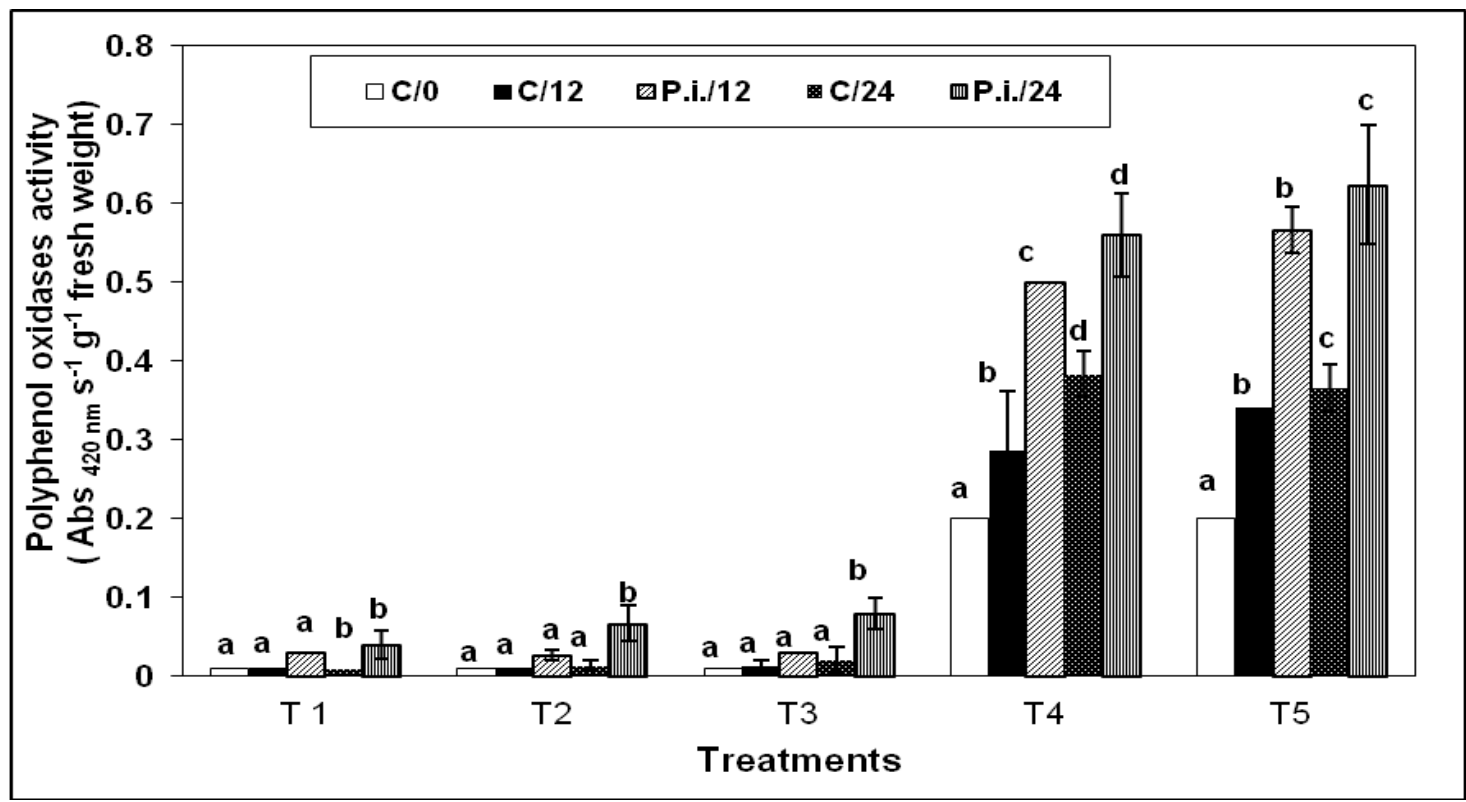

Figure 7. Peroxidase (a) and polyphenol oxidase (b) activities in post-harvest tubers.

Enzymatic activities in Innovator, Loberia 2009/10, were quantified in crude extracts of tuber from control and treated plants at various times after wounding or $P$. infestans inoculated. Treatments: $\mathrm{T} 1$ : Control; T2: Tebuconazole; T3:
Azoxystrobin + Difenoconazole; T4 and T5: Boscalid + Pyraclostrobin application at 60 and 75 DAP respectively. 


\section{Discussion}

The present research the results showed that foliar application of Boscalid + Pyraclostrobin offered better protection against early blight than other fungicides. Although some chemicals could induce resistance to pathogens, this is not always associated with yield increase (Abbasi et al. 2002). The crops treated with Boscalid + Pyraclostrobin showed a tendency to produce higher yields which could be associated with the effect on both GC (Figure 1), and GI (Figure 2), which finally impacted positively on the relationship between GCD and yield (Figure 3). It is well known for potatoes, and for other crops, that GC is highly correlated to tuber yield (Burstal and Harris 1983, Caldiz et al. 1999). Moreover, similar increments in tuber yield due to the application of Boscalid + Pyraclostrobin have also been reported (BASF 2005, BASF 2007).

There are mechanisms in the gene activation plant in cells neighboring the site of infection, producing the de novo synthesis of several secondary metabolites, such as phytoalexins and phenols with antibiotic and cytotoxic activities directed against the pathogens (Andreu et al. 2001; Wang et al. 2008) (Figure 5b).

The most important aspects of these results are the durability and the systemic nature of the defense response produced by Boscalid + Pyraclostrobin for a wide range of pathogens, evaluated in the cultivars of this experiment. The increase in the level of these compounds is of paramount importance, since most cultures for processing are stored for several months for their use, not only in Argentina but also in many other countries (Stark and Love 2003).

\section{Conclusions}

From the present results, it can be concluded that besides the properties as a fungicide to control early blight, Boscalid + Pyraclostrobin has a stay-green effect that positively impacts on tuber yield and quality. Moreover, these compounds play an important role in the development of IR. The latter is particularly important for potato tubers because in many cases, as it occurs with those for processing they are stored up to 6-8 months and the risk of potential infections would be reduced. While there is some limited evidence regarding the development of IR by systemic fungicides and strobilurins, this work constitutes the first evidence, of an anilide + strobilurin (Boscalid + Pyraclostrobin) as inducers of chemical disease resistance, in potatoes. A key factor to take into account, since the anilides belong to the green group (category IV) of agrochemicals.

\section{Conflicts of interest}

This article does not have any conflict of interest.

\section{Acknowledgements}

This research project was partially funded by McCain Argentina SA, BASF Argentina, Universidad Nacional de Mar del Plata and Consejo Nacional de Investigaciones Científicas y Tecnológicas (CONICET, Argentina).

\section{References}

Abbasi, P.A.; Al-Dahmani, J.; Sahin, F., Hoitink, H.A.J.; Miller, S.A. (2002). Effect of compost amendments on disease severity and yield of tomato in conventional and organic production systems. Plant Dis 86: 156-161.

Andreu, A.B.; Guevara, M.G.; Wolski, E.A.; Daleo, G.R.; Caldiz, D.O. (2006). Enhancement of the natural disease 
resistance of potatoes by chemicals. Pest Manag Sci 62: 162-170.

Andreu, A.B.; Oliva, C.R.; Distel, S.; Daleo, G.R. (2001). Production of phytoalexins, glycoalkaloids and phenolics in leaves and tubers of potato cultivars with different degrees of field resistance after infection with Phytophthora infestans. Potato Res 44: 19.

BASF Argentina. (2007). AgCelence® Excelencia que va más allá de la protección de sus cultivos. BASF Argentina SA. Buenos Aires, Argentina. $10 \mathrm{p}$.

BASF. (2005). Boscalid. The multipurpose fungicide for specialty crops and more. BASF Aktiengesellschaft Agricultural Center, Limburgerhof. Germany. 39 p.

Bray, H.; Thorpe, W. (1954). Analysis of phenolic compounds of interest in metabolism. Methods in Biochemical Analysis 1: 27-52.

Bruce, R.J.; West, C.A. (1982). Elicitation of casbene synthetase activity in castor bean: The role of pectic fragments of the plant cell wall in elicitation by a fungal endopolygalacturonase. Plant Physiol 69: 1181-1188.

Burstal, L.; Harris, P.M. (1983). The estimation of percentage light interception from leaf area index and percentage ground cover in potatoes. $\mathbf{J}$ Agr Sci 100: 241-244.

Caldiz, D.O.; Caso, O.H.; Vater, G.; Fernández, L.V. (1999). The potential for production of high quality seed potatoes in Tierra del Fuego Island, Argentina. Potato Res 42: 9-23.
Caldiz, D.O. (2004). Características y manejo de la variedad Innovator. Del Campo a la Fábrica 4 (4): 3-6.

CASAFE (2009). Guía de Productos Fitosanitarios, ed. CASAFE, Capital Federal, Argentina. Tomo 3, . 1945-3087.

Centro Internacional de la Papa (CIP) (1986). Método sencillo para interpretar el crecimiento y rendimiento del cultivo de papa. CIP Circular 14: 7-9.

Constantino, S. (2016). Argentina: La producción de papa 2015/16 alcanzó las 2,43 mill. de toneladas. Argenpapa, accesible at: http://www.argenpapa.com.ar/noticia/356 5-argentina-la-produccion-de-papa-2015/16 -alcanzo -las- 2-,43 -mill. -de toneladas. 4 p. Consulta: Enero 2017.

Chen, C.H.; Belanger, R.R.; Benhamou, N.; Paulitz, T.C. (2000). Defense enzymes induced in cucumber roots by treatment with plant growth-promoting rhizobacteria (PGPR) and Pythium aphanidermatum. Physiol Mol Plant Pathol 56: 13-23.

Escande, A.R.; Calderoni, A.V.; Melegari, A.L. (1984). La Papa. Diagnóstico y Control de sus Enfermedades. INTA Balcarce - Facultad de Ciencias Agrarias, UNMdP - CIAM. Balcarce, Mar del Plata, Argentina. 48 p.

Heil, M. (2001). The ecological concepts of costs of induced systemic resistance (ISR). Eur J Plant Pathol 107: 137-146.

Hernández, W.; Caldiz, D.O. (2006). Características y manejo de la variedad Daisy. Del Campo a la Fábrica 6 (3): 2-3.

Horsfall, J.G.; Barratt, R.W. (1945). An improved grading system for measuring plant diseases. Phytopathology 35: 655.

Mantecón, J. D. (2007). Potato yield increases due to fungicide treatment in Argentinian early blight (Alternaria 
solani) and late blight (Phytophthora infestans) field trials during the 19962005 seasons. Online. Plant Health Progress doi:10.1094/PHP-2007-020201-RS.

Mantecón, J.D. (2015). Fungicidas aplicados al suelo como estrategia de manejo integrado de enfermedades en papa, bajo escenarios de elevada infestación inicial y residual. Revista Latinoamericana de la Papa 19 (1): 29-39.

Napolitano, G.H. (2012). Estudio del sistema de agronegocios de la papa en la Argentina. MAGyP, SAGPyA, PROSAP, IICA. 72 p.

Olivieri, F.P.; Godoy, A.V.; Escande, A.; Casalongué, C.A. (1998). Analysis of intercellular washing fluid of potato tuber and detection of increased proteolytic activity upon inoculation with Fusarium eumartii. Physiol Plantarum 104: 232238.

Ryals, J.A.; Neuenschwander, U.H.; Willits, M.G.; Molina, A.; Steiner, H.Y.; Hunt, M.D. (1996). Systemic Acquired Resistance. The Plant Cell 8: 1809-1819.

Shih, M.; Kuc, J. (1973). Incorporation of 14C from acetate and mevalonate into rishitin and steroid glycoalkaloids by potato slices inoculated with Phytophthora infestans. Phytopathology 63: 826-829.
Soleiman, M.J.; Kirk, W. (2012). Enhance resistance to Alternaria alternata causing potato brown leaf spot disease by using some plant defense inducers. J. Plant Protec Res 52: 86-90.

Stark, J.C.; Love, S.L. (2003). Potato Production Systems. University of Idaho Agricultural Communications, Idaho, USA. 426 p.

Stevenson, W.R. (1993). Management of early blight and late blight, pp. 141-147. In: Rowe, R. C. (ed), Potato Health Management. The American Phytopathological Society, St. Paul, Minnesota, USA. 272 p.

Stevenson, W.R.; Loria, R.; Franc, G.D.; Weingartner, D.P. (2001). Compendium of Potato Diseases, second ed. The American Phytopathological Society, St. Paul, Minnesota, USA.. 106 p.

Wale, S.; Platt, H.W.; Cattlin, N. (2008). Diseases, Pests and Disorders of Potatoes. A Color Handbook. Academic Press Elsevier, Boston. 176 p.

Wang, X.; El Hadrami, A.; Adam, L.R.; Daayf, F. (2008). Differential activation and suppression of potato defense responses by Phytophthora infestans isolates representing US-1 and US-8 genotypes. Plant Pathol 57: 1026-1037.

Zar, J.H. (1999). Biostatistical Analysis. Prentice-Hall international editions, New Jersey. USA. 663 p. 